\title{
Circulating IL17a and IFN-Gamma Serum Levels in Cirrhotic Hepatitis C Virus Infected Patients with Autoimmune Thyroiditis
}

\author{
Helal F. Hetta ${ }^{1}$, Azza Elkady ${ }^{1}$, Khairy H. Morsy ${ }^{2}$, Ismail S Mohamed ${ }^{1}$ \\ Khaled M. Hassanein ${ }^{1}$, Tohamy A. Tohamy ${ }^{3}$, Hala M. EIBadre ${ }^{4}$ and \\ Ghada A. Mohamed ${ }^{5}$ \\ ${ }^{1}$ Department of Medical Microbiology and Immunology, Faculty of Medicine, \\ Assiut University, Assiut, Egypt \\ ${ }^{2}$ Department of Tropical medicine and gastroenterology, Faculty of Medicine, \\ Sohag University, Sohag, Egypt \\ ${ }^{3}$ Medical Research center, Assiut University, Egypt \\ ${ }^{4}$ Department of Biochemistry, Faculty of Medicine, Assiut University, Egypt \\ ${ }^{5}$ Department of Internal medicine, Faculty of Medicine, Assiut University, Egypt \\ *Corresponding author
}

\section{A B S T R A C T}

\begin{tabular}{|l|}
\hline K e y w o r d s \\
Interleukin 17, \\
Interferon gamma, \\
HCV, Autoimmune, \\
ANA, TH1, Th17, \\
ICA, TPO, T1D. \\
\hline Article Info \\
\hline $\begin{array}{l}\text { Accepted: } \\
\text { 25 February } 2017 \\
\text { Available Online: } \\
\text { 10 March } 2017\end{array}$ \\
\hline
\end{tabular}

Autoimmune endocrine disorders are considered one of the extrahepatic manifestations of Hepatitis $\mathrm{C}$ virus (HCV) infection. HCV could trigger cytokines release due to local inflammation. Interleukin 17 a (IL17a) and Interferon gamma (IFN $\gamma$ ) play an important role in pathogenesis of autoimmune disease. Herein, we tried to assess the serum levels of IL17a and IFN-gamma in cirrhotic HCV infected patients with autoimmune thyroiditis. Serum samples were collected from 183 cirrhotic HCV infected patients. Sera were screened for antinuclear antibody (ANA) by ELISA and those who were positive for ANA $(n=40)$ were screened for Thyroid peroxidase (TPO) antibodies by indirect Immunofluorescence. IL17a and IFN $\gamma$ serum level were measured by ELISA in ANA positive HCV group $(n=40)$, ANA negative HCV group $(n=24)$ and compared to a healthy control group $(\mathrm{N}=24)$. Forty patients $(21.8 \%)$ were found positive for ANA. Seventeen patients were reported positive for TPO (42.5\%). Serum IL17a and IFN-gamma levels were significantly higher in TPO, ANA- positive group than ANA- negative group $(\mathrm{P}<0.005),(\mathrm{P}<0.05)$ and control group $(\mathrm{P}<0.0001),(\mathrm{P}=0.09)$ respectively. The elevated serum level of IL17a and IFN-gamma in cirrhotic HCV patients with autoimmune thyroiditis suggests that these cytokines play a role in the pathogenesis of autoimmune disorders related to $\mathrm{HCV}$ extrahepatic manifestations.

\section{Introduction}

Globally, Approximately 200 million people become infected with HCV worldwide and 350,000 people per year die from the disease (Joshi and Kumar, 2015).
HCV can cause significant damage to the liver, including cirrhosis reaching to hepatocellular carcinoma (Ferrell, 2000). 
Egypt has the highest prevalence of $\mathrm{HCV}$ infection in the world with an estimated prevalence in the general population of 14 . $7 \%$. HCV genotype 4 is the most predominant isolated genotype from $90 \%$ of the $\mathrm{HCV}$ infected patients in Egypt (Elhawary et al., 2011). The geographical distribution of the prevalence levels is higher in the rural area than urban settings and Lower Egypt (Cuadros et al., 2014; Rafik et al., 2016).

$\mathrm{HCV}$ infection is associated with immune mediated extrahepatic manifestations (Hetta et al., 2016)including cryoglobulinaemia, lichen planus, porphyria cutanea tarda, lymphocytic sialoadenitis and membranous glomerulonephritis (Zignego et al., 2007).

$\mathrm{HCV}$ infection tends to promote non-specific autoimmune reactions, as demonstrated by the high prevalence of various non-organ-specific autoantibodies, usually in low titers (Rodrigues-Pinto et al., 2015). Serum autoantibodies as anti-nuclear antibody (ANA) and smooth muscles antibodies (SMA) were detected in chronic $\mathrm{HCV}$ patients. It was recorded that the prevalence of serum autoantibodies is higher in HCV positive patients than in healthy population.(Khairy et al., 2013a)The presence of serum ANA is associated with various factors including advancing age, genetic predisposition, environmental agents, oestrogenandrogen balance, chronic infection and neoplasm (Hsieh et al., 2012a). Autoimmune endocrine disease is one of the most common extrahepatic manifestation. Autoimmune diabetes or T1D and autoimmune thyroiditis is considered one of the most common endocrine disorders.Many studies have evaluated the prevalence of thyroid autoantibodies in patients with cirrhotic HCV infection.(Betterle and Presotto, 2012).

HCV could trigger autoimmune diseases by several mechanisms. Induction of local inflammation by cytokines release which in turn result in activation of autoreactive T-cell (by-stander mechanism) (Akeno et al., 2008). Herein, we tried to assess the serum levels of IL17a and IFN-gamma in cirrhotic HCV infected patients with autoimmune thyroiditis.

\section{Materials and Methods}

\section{Patient recruitment}

The study includes patients with chronic hepatitis $\mathrm{C}$ and hospitalized at the department of Tropical Medicine Department, Sohag University Hospital and Sohag Center of Cardiac and Digestive System. All patients were positive for HCV antibodies by ELISA and HCV RNA by Real time PCR (RT-PCR). The patient group includes 75 females and 108 males, with mean age of $55.26 \pm 8.04$ years old. All patients were subjected to history taking, clinical examination, liver function test and abdominal ultrasonography. Verbal and signed consent forms were obtained from participants according to an IRB protocol approved by Sohag University, College of Medicine Institutional Review Board.

Exclusion criteria included patients with hepatitis B virus infection, patient with HIV infection, patients who had received antiviral drugs, steroids, or immune suppressive drugs, patients who had other causes of chronic liver injury such as alcohol intake and pregnancy.

In addition, the study included 24 healthy blood donors as a control group with a mean age of $50 \pm 9$ years old. They were negative for known serological markers of $\mathrm{HBV}$ and $\mathrm{HCV}$ infections including hepatitis B surface antigen (HBsAg) and anti-HCV

The study protocol was approved by local ethical committee. 
A Schematic presentation of the study design and the number of subjects enrolled in each group is presented in figure 1.

\section{Methods}

Ten $\mathrm{ml}$ blood were obtained from each subject into sterile tubes without any anticoagulant. Blood samples were spun down at 3000 r.p.m for 10 minutes.

The Serum was divided into aliquots labeled appropriately and stored at $-20 \mathrm{C}$.

\section{Detection of antinuclear-antibody (ANA) in the serum of cirrhotic $\mathrm{HCV}$-infected patients}

Screening of antinuclear antibodies (ANA) was done in serum of 183 cirrhotic (HCV) infected patients by Enzyme linked immunosorbent assay (ELISA) kits purchased from Dr, Fenning Biomed Gmbh, Germany Cat NO.11029.

Samples with ratio > 1.4 are considered positive, samples within range 1-1,4 are considered borderline. Sample $<1.0$ are considered negative.

The negative results indicate that there is no detectable antinuclear-antibodies among chronic (HCV) infected patients.

\section{Examination of anti-thyroid antibody} (ATA)

Thyroid autoantibodies were tested in patients in sera of forty patients with chronic hepatitis $\mathrm{C}$ and positive for ANA by indirect immunofluorescence assay. (ImmuGIo $^{\mathrm{TM}}$ Anti-Thyroid Antibody Test System Code No.1143, from IMMCO Diagnostic, USA) according to the manufacturer's instructions.Briefly, Fifty $\mu$ l of diluted serum wasincubated with anti-human IgG FITC
Conjugate containing Evan's Blue for 30 minutes. Slides were washed with PBS, mounted with mounting media and examined under fluorescence microscope.

\section{Cytokines assay}

IL17a and IFN-gamma concentrations in the patient's serum were quantitatively measured by Enzyme linked immunosorbent assay (ELISA) using Koma Biotech IL17a human ELISA Kit (Cat No. k0331207) and IFNgamma human ELISA kit (Cat No. k0331121). Concentrations were calculated from standard curves using recombinant proteins and expressed in $\mathrm{pg} / \mathrm{ml}$.

\section{Statistical analysis}

Data are presented as range (minimum, maximum); and mean \pm SD. Continuous variables ALT, AST, were expressed as the arithmetic mean \pm SD and were compared between the enrolled patients using Student's t test, or Wilcoxon Rank Sum Test, as appropriate with a significance value at $\mathrm{p} \leq$ 0.05 . The ANOVA test was used to examine the difference between groups of the enrolled subjects, as appropriate. Correlations between parameters measured were calculated using Spearman's correlation coefficient. All statistical analyses were completed with the help of Graph Pad Prism 7 Software (San Diego, California, USA).

\section{Results and Discussion}

This study includes 183 chronically HCV infected patients. 75 (40.9\%) females and 108 (59\%) males with mean age of $55.26 \pm 8.04$, ALT mean level of $33.47 \pm 11.69$ and AST

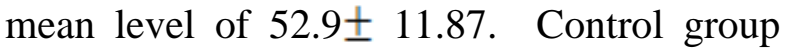
was formed of $10(41 \%)$ females and 14 (58.3\%) males with a mean age of $50 \pm 8.1$, ALT mean of $22 \pm 8.5$ and AST level mean $23.4 \pm 8.2$. 
Patients with chronic HCV were significantly older (mean+ SD 55.26 \pm 8.04 ) than the control group (mean+SD; 41.42 \pm 10.32 , $\mathrm{P}<0.0001)$.

The ALT level was significantly higher in patients with chronic HCV (mean+SD; $33.47 \pm 11.96)$ than the control group (mean+SD; 22.96 $\pm 6.18, \mathrm{P}<0.0001$ ). The AST level was significantly higher in patients with chronic HCV (mean+SD 51.11 \pm 16.79$)$ than the control group (mean+SD; 22.17 \pm 7.29 , $\mathrm{P}<0.0001)$. Demographic and clinical characteristics of the subject groups were summarized in table 1 .

\section{Characterization of $\mathrm{HCV}$ patients positive for ANA}

The anti-nuclear antibody (ANA) was tested in all patients with cirrhotic hepatitis C. Accordingly the patients were classified according to the positivity of ANA into ANA positive patients and ANA negative patients.

ANA-positive cases were $n=40(21.8 \%)$ and negative cases were $n=143$. Among the ANApositive cases, the mean age was $52.93 \pm$ 12.77, where the mean age of negative group was $55.91 \pm 6.009$; male patients represent $55 \%$ of total positive cases where female represent $45 \%$.

Concerning the baseline laboratory data of both groups, Serum ALT and AST level was significantly higher in ANA-positive cases than ANA-negative cases, and between ANApositive cases and healthy control group while there was no significant difference in the mean age between ANA-positive and ANAnegative group as shown in table 2 .

\section{Serum cytokines level in different groups}

Serum IL17a and IFN-gamma levels were measured in three groups; the first group include forty ANA-positive case, second one include twenty-four ANA-negative case, and the third include twenty-four healthy control group. Serum IL17a level was significantly higher in ANA-positive (mean \pm SD 40.41 \pm 39.5 ) than ANA-negative (mean \pm SD 24.92 \pm 47.28$)(P=0.0019)$ and control healthy group (mean \pm SD $1.65 \pm 5.59) \quad(P<0.0001)$ as shown in table 3.

Additionally, serum IFN-gamma level was significantly higher in ANA-positive group (mean \pm SD10.05 \pm 9.722) than ANA-negative group (mean $\pm S D 4.15 \pm 3.07) \quad(\mathrm{P}=0.0117)$ and control healthy group (mean $\pm S D 4.27 \pm$ 3.61) $(\mathrm{P}=0.0027)$ as shown in table 3.

There is strong correlation between serum level of IL17a and ALT level $(\mathrm{P}=0.03)$

Pearson factor $(\mathrm{r}=0.3)$ as shown in figure 2 . On the other hand, there were no significant correlation between IFN gamma and ALT.

\section{Incidence of anti thyroperoxidase antibodies (TPO Ab)}

Antibodies against thyroperoxidase (TPOAb) were tested in serum samples collected from 40 patients with chronic hepatitis $\mathrm{C}$ and positive for ANA. Seventeen patients (42.5 $\%$ ) were positive for TPOAB (Figure 3 ).

\section{Characterization of patients with positive TPO}

The anti thyroperoxidase antibodies were tested in cirrhotic hepatitis $\mathrm{C}$ infected patients characterized with positive (ANA) $(n=40)$. Accordingly, the patients were classified according to the positivity of TPO $\mathrm{Ab}$ into TPO positive patients and TPO negative patients.

TPO-positive cases were $\mathrm{n}=17(42.5 \%)$ and negative cases were $n=23$. Among the TPOpositive cases, the mean age was 
(54.65 \pm 6.05$)$, where the mean age of negative group was $(55.43 \pm 6.84)$; male patients represent $58.8 \%$ of total positive cases where female represent $41.1 \%$. Concerning the baseline laboratory data of both groups, there was no significant difference in the mean serum level of ALT, AST and ANA between the two groups as shown in table 4 and figure 4.

Table.1 Demographic and clinical characteristics of the studied groups

\begin{tabular}{|c|c|c|c|}
\hline & $\begin{array}{c}\text { Total chronic HCV } \\
\text { infected } \\
\text { Patients } \mathrm{n}=183\end{array}$ & $\begin{array}{c}\text { Control healthy } \\
\mathrm{n}=24\end{array}$ & $\mathrm{P}$ value \\
\hline $\begin{array}{c}\mathrm{ALT} \\
(\mathrm{mean} \pm s d)\end{array}$ & $33.47 \pm 11.96$ & $22.96 \pm 6.18$ & $\mathrm{P}<0.0001$ \\
\hline $\begin{array}{c}\mathrm{AST} \\
(\mathrm{mean} \pm s d)\end{array}$ & $51.11 \pm 16.79$ & $22.17 \pm 7.29$ & $\mathrm{P}<0.0001$ \\
\hline $\begin{array}{c}\text { Age } \\
(\mathrm{mean} \pm s d)\end{array}$ & $55.26 \pm 8.04$ & $41.42 \pm 10.32$ & $\mathrm{P}<0.0001$ \\
\hline $\begin{array}{c}\text { Gender } \\
\text { Male: } \text { female }\end{array}$ & $108(59 \%): 75(40.9 \%)$ & $14: 10$ & 1 \\
\hline
\end{tabular}

Table. 2 clinical characterization of ANA-positive and ANA-negative groups

\begin{tabular}{|c|c|c|c|c|c|c|}
\hline & $\begin{array}{c}\text { ANA (+) } \\
(\mathrm{n}=40)\end{array}$ & $\begin{array}{c}\text { ANA (-) } \\
(\mathrm{n}=143)\end{array}$ & $\begin{array}{c}\text { Control } \\
\text { healthy } \\
\mathrm{n}=24\end{array}$ & $\begin{array}{c}\text { P-value } \\
\text { Between } \\
\text { Groups } \\
\text { ANOVA }\end{array}$ & $\begin{array}{c}\text { P-value } \\
\text { ANA (+) } \\
\text { Vs } \\
\text { ANA (-) }\end{array}$ & $\begin{array}{c}\text { P-value } \\
\text { ANA (+) } \\
\text { Vs } \\
\text { Control healthy }\end{array}$ \\
\hline $\begin{array}{c}\text { ALT } \\
\text { mean } \pm S D\end{array}$ & $38.08 \pm 8.74$ & $32.2 \pm 12.44$ & $22.96 \pm 6.18$ & $0.013^{*}$ & $0.0006^{*}$ & $0.0001^{*}$ \\
\hline $\begin{array}{c}\text { AST } \\
\text { mean } \pm S D\end{array}$ & $56.33 \pm 15.32$ & $48.24 \pm 15.5$ & $22.17 \pm 7.29$ & $0.009^{*}$ & $0.0008^{*}$ & $0.0001^{*}$ \\
\hline $\begin{array}{c}\text { AGE } \\
\text { mean } \pm S D\end{array}$ & $\begin{array}{c}52.93 \pm \\
12.77\end{array}$ & $55.91 \pm 6.009$ & $41.42 \pm 10.32$ & $0.0001^{*}$ & 0.493 & $0.0001^{*}$ \\
\hline $\begin{array}{c}\text { Gender } \\
\text { Male }: \\
\text { Female }\end{array}$ & $\begin{array}{c}22(55 \%): 18 \\
(45 \%)\end{array}$ & $86: 57$ & $14: 10$ & 1 & 0.5 & 1 \\
\hline
\end{tabular}

Table.3 Mean of serum cytokines levels in ANA positive, ANA negative and control healthy group

\begin{tabular}{|c|c|c|c|c|c|}
\hline & $\begin{array}{c}\text { ANA (+) } \\
n=40\end{array}$ & $\begin{array}{c}\text { ANA (-) } \\
\text { n=24 }\end{array}$ & $\begin{array}{c}\text { Control } \\
n=24\end{array}$ & $\begin{array}{c}\text { P-value } \\
\text { ANA (+)Vs } \\
\text { ANA (-) }\end{array}$ & $\begin{array}{c}\text { P-value } \\
\text { ANA (+)Vs } \\
\text { Control healthy }\end{array}$ \\
\hline $\begin{array}{c}\text { IL17a } \\
\text { mean } \pm S D \text { Pg/ml }\end{array}$ & $40.41 \pm 39.5$ & $24.92 \pm 47.28$ & $1.65 \pm 5.59$ & $\mathrm{P}=0.0019^{*}$ & $\mathrm{P}<0.0001^{*}$ \\
\hline $\begin{array}{c}\text { IFN-gamma } \\
\text { mean } \pm S D \mathrm{Pg} / \mathrm{ml}\end{array}$ & $10.05 \pm 9.722$ & $4.15 \pm 3.07$ & $4.27 \pm 3.61$ & $\mathrm{P}=0.0117^{*}$ & $\mathrm{P}=0.0027^{*}$ \\
\hline
\end{tabular}


Table.4 Comparison of the mean of ANA, ALT, AST, IL17a, IFN-gamma between positive TPO and negative TPO group

\begin{tabular}{|c|c|c|c|}
\hline & $\begin{array}{c}\text { TPO (+) } \\
\mathbf{n = 1 7}\end{array}$ & $\begin{array}{c}\text { TPO (-) } \\
\mathbf{n = 2 3}\end{array}$ & P-value \\
\hline $\begin{array}{c}\text { IL17a } \\
\text { mean } \pm S D \text { Pg/ml }\end{array}$ & $48.01 \pm 38.35$ & $34.79 \pm 40.23$ & $\mathrm{P}=0.1$ \\
\hline $\begin{array}{c}\text { IFN-gamma } \\
\text { mean } \pm \text { SD Pg/ml }\end{array}$ & $14.89 \pm 11.17$ & $7.33 \pm 7.74$ & $\mathrm{P}=0.013^{*}$ \\
\hline ANA & $2.818 \pm 2.94$ & $2.003 \pm 0.66$ & $\mathrm{P}=0.12$ \\
\hline ALT IU/ml & $39.35 \pm 10.78$ & $37.04 \pm 6.9$ & $\mathrm{P}=0.3$ \\
\hline AST IU/ml & $59.59 \pm 18.82$ & $53.91 \pm 12.01$ & $\mathrm{P}=0.8$ \\
\hline $\begin{array}{c}\text { Age } \\
\text { mean } \pm \boldsymbol{S} \boldsymbol{D}(\mathbf{y e a r s})\end{array}$ & $54.65 \pm 6.05$ & $55.43 \pm 6.84$ & $\mathrm{P}=0.7$ \\
\hline $\begin{array}{c}\text { Gender } \\
\text { Male: female }\end{array}$ & $10: 7$ & $12: 11$ & $\mathrm{P}=0.75$ \\
\hline *significant & & & \\
\hline
\end{tabular}

*significant

Figure.1 Schematic presentation of the study design and the number of subjects enrolled in each group

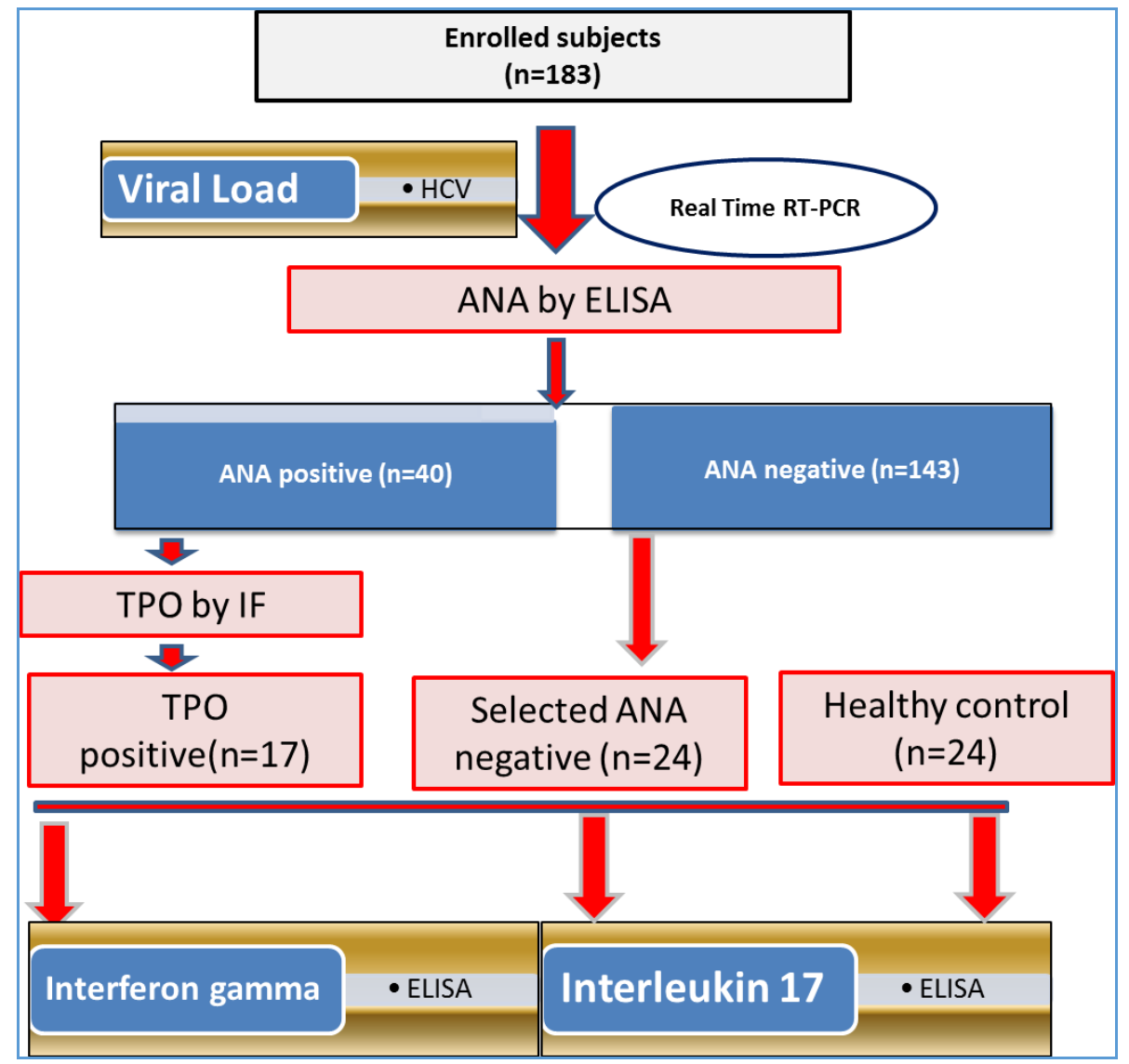


Figure.2 Correlation between IL17a serum level and ALT level. There was a significant positive correlation between IL17a and ALT serum levels $(\mathrm{P}=0.03, \mathrm{r}$ $=0.3)$

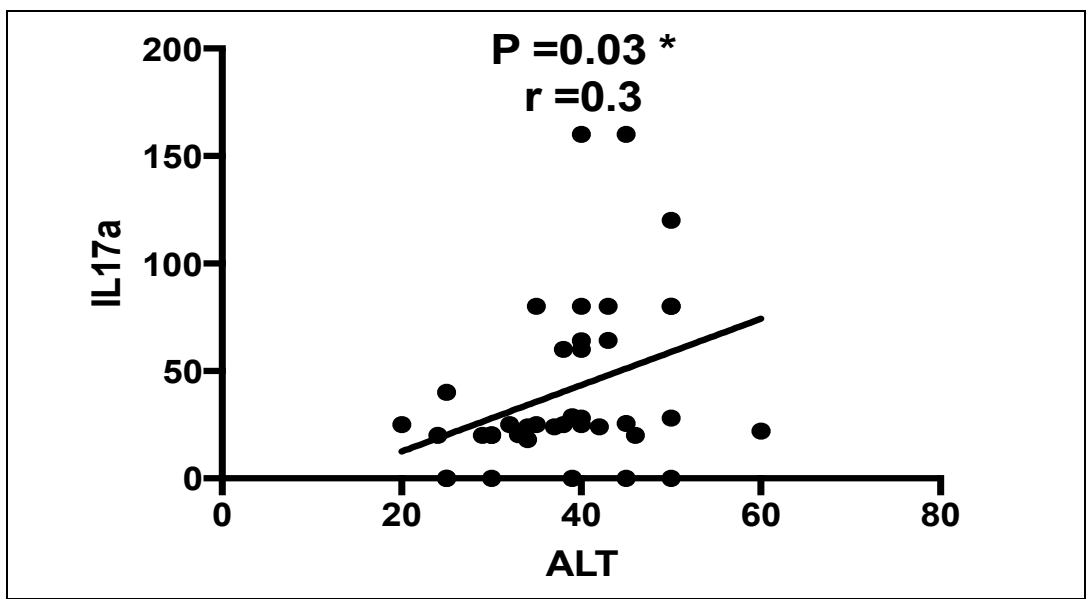

Figure.3 Representative apple green fluorescence of the autoantibodies in the, cytoplasm of epithelial cells in the thyroid follicle

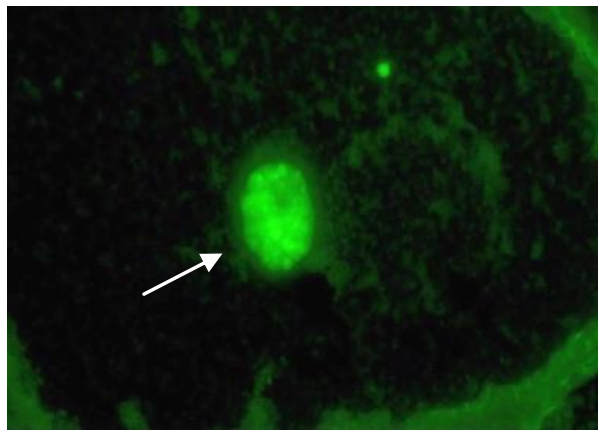

Figure.4 Comparison of mean of ANA, ALT, AST, IL17a, IFN-gamma between positive TPO and negative TPO group

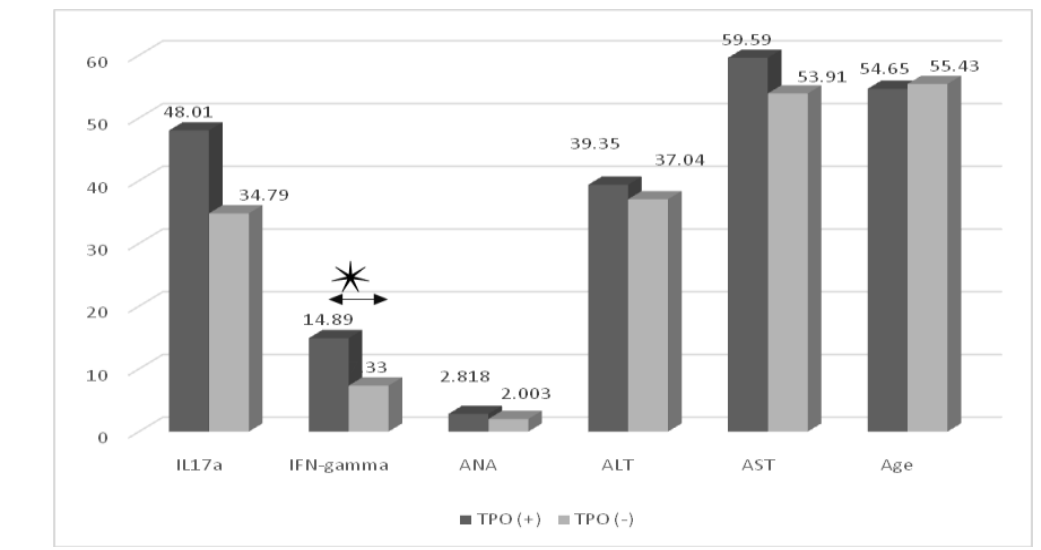

$* \mathrm{P}=0.013$ 
Figure.5 Comparison of IL17a serum level between (a) Positive TPO, ANA group and negative (TPO, ANA). (b) Positive (TPO, ANA) group and control healthy group

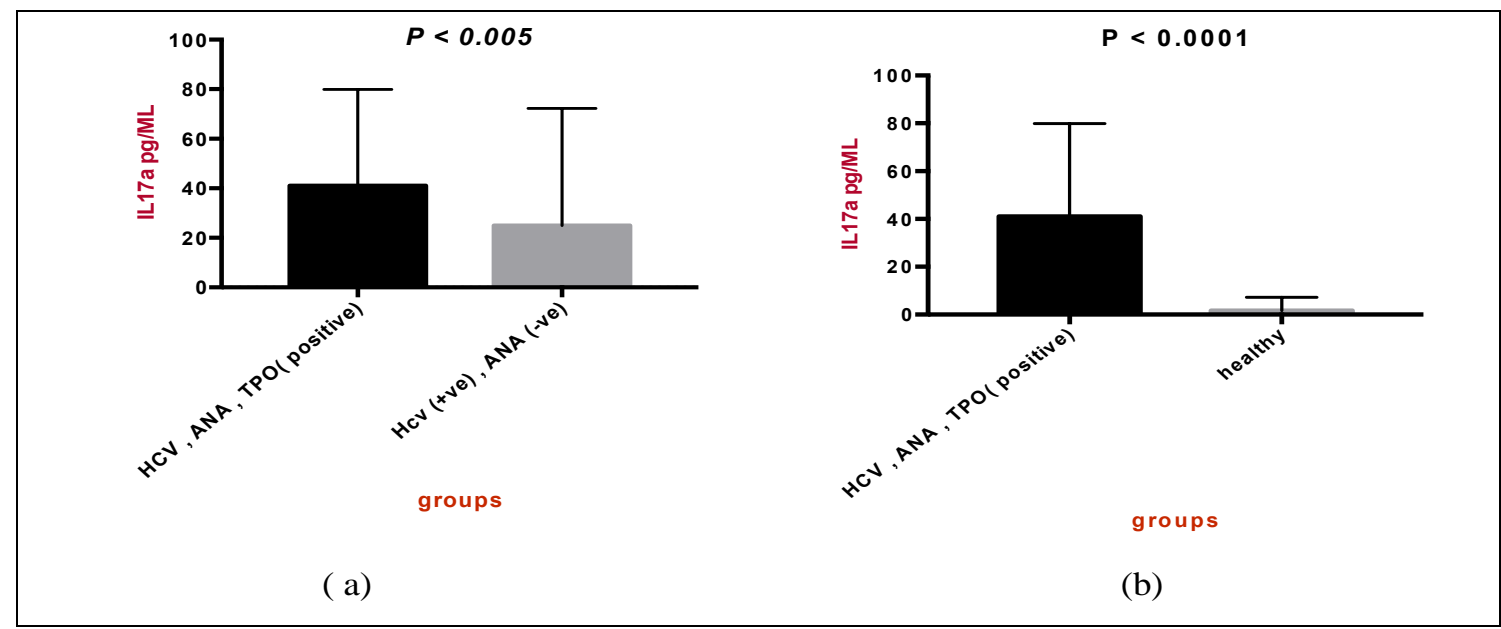

Figure.6 Comparison of IFN-gamma serum level between (a) Positive TPO,ANA group and negative (TPO, ANA). (b) Positive (TPO, ANA) group and control healthy group

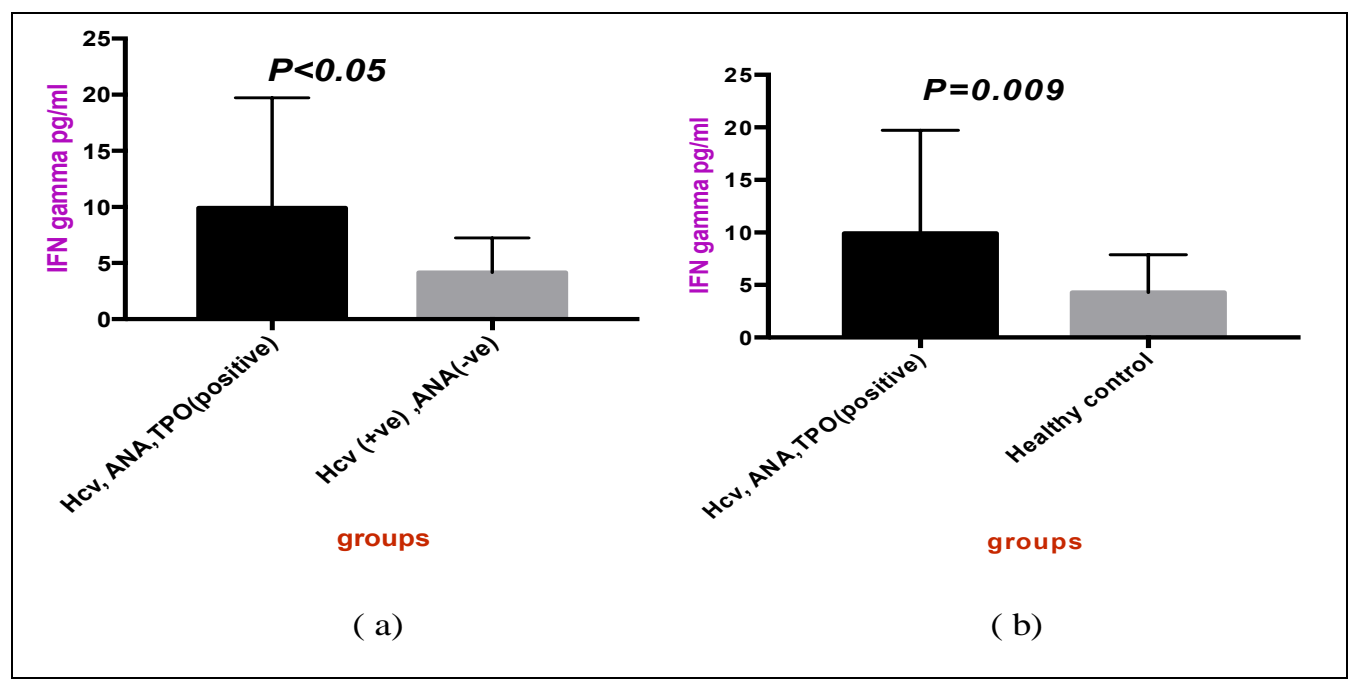

There was a significant difference in the serum level of IFN- gamma between TPOpositive and TPO-negative group $(\mathrm{P}=0.013)$. On the other hand, there was no significant difference in the serum level of IL17a between the two group $(\mathrm{P}=0.1)$.

Serum level of IL17a was significantly higher in TPO, ANA positive patients compared to ANA- negative patients, (mean \pm SD level; 48.01 $\pm 38.35, \mathrm{P}<0.005)$.
Also results show a higher significant level in positively TPO group compared to control healthy group $(\mathrm{P}<0.0001)$ as shown in figure $5 a, b$.

On the other hand, serum IFN gamma level was significantly higher in TPO positive patients compared to (ANA, TPO) negative patients (mean $\pm \mathrm{SD} ; 14.89 \pm 11.17, \mathrm{P}<0.05$ and control healthy group $(\mathrm{P}=0.009)$. As shown in figure $6 a, b$. 
More than $50 \%$ of $\mathrm{HCV}$ infected patients has one or more of extrahepatic manifestations. $\mathrm{HCV}$ play role in the pathogenesis of immunological alteration.

In our study, high prevalence of ANA positive cases $(21.8 \%)$ was observed among cirrhotic $\mathrm{HCV}$-infected patients. This high prevalence of ANA positive cases can be attributed to the severity of liver cirrhosis and inflammation. Our results were in consistence with Yehia S. younus et al study who found a statistically significant difference between ANA-positive and ANA negative groups as regards activity grades $(\mathrm{P}$-value $=0.019)$ and fibrosis stage $(\mathrm{P}$-value $=0.012)($ Rania I.Mabrouk Yehia s.Younes 2015).

Similarly, Hsieh et al(Hsieh et al., 2012b), Yee et al (Yee et al., 2004)and Squadrito et al (Squadrito et al., 2003) found association between the antinuclear autoantibody reactivity and severity of liver fibrosis and cirrhosis.

On the other hand, Khairy et al concluded that fibrosis stage and the degree of inflammation were not influenced by ANA positivity in his study (Khairy et al., 2013b).

In the present study, serum ALT and AST level were significant elevated in ANA positive group than ANA negative group (pvalue $>0.0001)$. This results come in accordance with Sezaki et al who reported that ALT level is higher in patients with autoimmune diseases (Sezaki et al., 2003).

In this study, males were likely to have ANA positive than females (55\% vs $45 \%$ ). This results was agreed with Khairy et al (Khairy et al., 2013b), Peng et al (Peng et al., 2001) and Yehia et al (Rania I.Mabrouk Yehia s.Younes 2015)results.

In contrary Hsieh et al found that woman a significant prevalence than men $(41.2 \%$ vs $31.0 \% \mathrm{p}=0.01)$. The difference in the results may be attributed to the large number of patients included in his study $(\mathrm{n}=614)$. (Hsieh et al., 2012b).

Several studies have linked TH1 and TH17 immune response with $\mathrm{HCV}$ infection. IFNgamma is clearly augment in the serum of cirrhotic HCV-infected patients.(Tilg et al., 2006).

Interestingly, our study reported a higher significant difference in level of IFN-gamma in ANA positive group compared to ANA negative group $(\mathrm{P}=0.0117)$ and control group $(\mathrm{P}=0.0027)$.

The increase in the level and expression of IFN-gamma has been correlated with severity of liver inflammation and cirrhosis. (Fallahi et al., 2012; Gonzalez-Peralta et al., 1994).

Several studies mentioned the role of IFNgamma in non-organ autoimmune disease related to $\mathrm{HCV}$ infection (Tarantino et al., 2009).

Collectively, these finding could suggest the high level of IFN-gamma in cirrhotic HCV patients characterized by ANA positive than other groups.

Also in our study we reported that there is a higher significant difference in the level of IL17a in the ANA positive group compared to ANA negative $(\mathrm{P}=0.0019)$ and control healthy group $(\mathrm{P}<0.0001)$.

A recent study found that serum IL-17 levels were significantly higher in chronically HCV infected patients than controls and the highest serum IL-17 levels were observed in LC patients. This higher serum IL-17 in patients with chronic liver disease goes with what has been reported previously that serum IL-17 
level was increased in liver injuries following chronic hepatitis and cirrhosis supporting a role for IL-17 as a chronic disease inducer in the pathogenesis and/or progression of liver fibrosis (Hassan et al., 2014).IL17 can activate a variety of immune cells to release inflammatory mediators which in turn lad to repeated inflammation of the liver(Harada $e t$ al., 2009).This could explain the strong positive correlation between IL17aserum level and ALT level $(r=0.3, P=0.03)$ in our study. Also it can explain the higher level of IL17a in ANA positive group than other groups in our study.

A recent study reported that the relationship between Th17 and ANA sera, demonstrated that some $\mathrm{T}$ helper related cytokines, especially IL-12, IL-17, IL-23, IL-6, IL-21, IL-22, and IFN-gamma differed in different ANA positive sera, suggesting that these cytokines play different roles in autoimmune diseases(Hu et al., 2015; Hu et al., 2013)

In this study out of the forty patients who were characterized positive ANA, there were seventeen patients (42.5\%) developed positive Thyroperoxidase autoantibodies.

Also there was a higher significant difference in level of IL17a and IFN-gamma between positive TPO group and negative (TPO, ANA) group and with control healthy group. These results could explain the high prevalence of ICA and TPO among chronic HCV patients characterized by positive ANA. These results are supported by the findings of Pastore F et al who reported that IL17 has a role in inducing autoimmune thyroiditis among HCV infected patients(Pastore et al., 2016).

From the whole above results it is possible to provide evidence for (bystander action) theory which proposed that viral infection of certain tissue as thyroid gland could induce the local inflammation and hence release of cytokines as IL17 and IFN-gamma.

\section{Abbreviations}

HCV, Hepatitis C Virus; CHC, Chronic Hepatitis C; ALT, Alanine aminotransferase;AST, Aspartate aminotransferase; IF, Immunofluorescence; TPO, Thyroperoxidase enzyme; IFN$\gamma$,Interferon gamma; ANA, Antinuclear antibody; IL17a, Interleukin 17a.

\section{Acknowledgement}

We would like to thank the entire participants in this study, particularly the patients. We thank the Grant office, Faculty of Medicine, Assiut University, Egypt for their financial support.

\section{References}

Akeno, N., Blackard, J. T. and Tomer, Y. (2008). HCV E2 protein binds directly to thyroid cells and induces IL-8 production: a new mechanism for $\mathrm{HCV}$ induced thyroid autoimmunity. Journal of autoimmunity31, 339-344.

Betterle, C. and Presotto, F. (2012). OrganSpecific Autoimmunity in $\mathrm{HCV}$ Positive Patients. In HCV Infection and Cryoglobulinemia, pp. 43-51: Springer.

Cuadros, D. F., Branscum, A. J., Miller, F. D. and Abu-Raddad, L. J. (2014). Spatial epidemiology of hepatitis $\mathrm{C}$ virus infection in Egypt: analyses and implications. Hepatology60, 1150-1159.

Elhawary, E. I., Mahmoud, G. F., El-Daly, M. A., Mekky, F. A., Esmat, G. G. and Abdel-hamid, M. (2011). Association of HCV with diabetes mellitus: an Egyptian case-control study. Virology Journal8, 367.

Fallahi, P., Ferri, C., Ferrari, S. M., Corrado, A., Sansonno, D. and Antonelli, A. (2012). Cytokines and HCV-related disorders. Clin Dev Immunol2012, 468107. 
Ferrell, L. (2000). Liver pathology: cirrhosis, hepatitis, and primary liver tumors. Update and diagnostic problems. Mod Pathol13, 679-704.

Gonzalez-Peralta, R. P., Fang, J. W., Davis, G. L., Gish, R., Tsukiyama-Kohara, K., Kohara, M., Mondelli, M. U., Lesniewski, R., Phillips, M. I. and other authors (1994). Optimization for the detection of hepatitis $\mathrm{C}$ virus antigens in the liver. J Hepatol20, 143-147.

Harada, K., Shimoda, S., Sato, Y., Isse, K., Ikeda, H. and Nakanuma, Y. (2009). Periductal interleukin-17 production in association with biliary innate immunity contributes to the pathogenesis of cholangiopathy in primary biliary cirrhosis. Clinical and experimental immunology157, 261-270.

Hassan, E. A., El, A. S. E.-D. A., Ahmed, A. O., Elsherbiny, N. M. and Elhagag, N. A. E.-R. A. (2014). The Impact of Serum Interleukin-17 on Chronic Hepatitis C and Its Sequelae. Journal of Liver2014.

Hetta, H. F., Mekky, M. A., Khalil, N. K., Mohamed, W. A., El-Feky, M. A., Ahmed, S. H., Daef, E. A., Medhat, A., Nassar, M. I. and other authors (2016). Extra-hepatic infection of hepatitis C virus in the colon tissue and its relationship with hepatitis $\mathrm{C}$ virus pathogenesis. Journal of medical microbiology65, 703-712.

Hsieh, M.-Y., Dai, C.-Y., Lee, L.-P., Huang, J.-F., Chuang, W.-L., Hou, N.-J., Lin, Z.-Y., Chen, S.-C., Hsieh, M.-Y. and other authors (2012a). Antinuclear antibody titer and treatment response to peginterferon plus ribavirin for chronic hepatitis $\mathrm{C}$ patients. The Kaohsiung journal of medical sciences 28, 86-93.

Hsieh, M.-Y., Dai, C.-Y., Lee, L.-P., Huang, J.-F., Chuang, W.-L., Hou, N.-J., Lin, Z.-Y., Chen, S.-C., Hsieh, M.-Y. and other authors (2012b). Antinuclear antibody titer and treatment response to peginterferon plus ribavirin for chronic hepatitis $\mathrm{C}$ patients. The Kaohsiung Journal of Medical Sciences28, 86-93.

Hu, J., Zhang, Y., Liu, X., Wei, L. and Zhang, D. (2015). Relationship between certain $\mathrm{T}$ helper cytokines and ANA staining: Who is the helper? International immunopharmacology24, 208-210.

Hu, J., Meng, W., Zhang, D., Qiu, C., Hua, L., Xie, Q., He, X. and Ye, H. (2013). Th17-relevant cytokines vary with sera of different ANA staining patterns. International immunopharmacology 15 , 679-684.

Joshi, V. and Kumar, A. (2015). Diabetes: a risk factor for mortality from brain stroke. Indian Journal of Pharmaceutical and Biological Research3, 28.

Khairy, M., El-Raziky, M., El-Akel, W., Abdelbary, M. S., Khatab, H., El-Kholy, B., Esmat, G. and Mabrouk, M. (2013a). Serum autoantibodies positivity prevalence in patients with chronic $\mathrm{HCV}$ and impact on pegylated interferon and ribavirin treatment response. Liver International33, 15041509.

Khairy, M., El-Raziky, M., El-Akel, W., Abdelbary, M. S., Khatab, H., El-Kholy, B., Esmat, G. and Mabrouk, M. (2013b). Serum autoantibodies positivity prevalence in patients with chronic $\mathrm{HCV}$ and impact on pegylated interferon and ribavirin treatment response. Liver international : official journal of the International Association for the Study of the Liver33, 1504-1509.

Pastore, F., Martocchia, A., Stefanelli, M., Prunas, P., Giordano, S., Toussan, L., Devito, A. and Falaschi, P. (2016). Hepatitis $\mathrm{C}$ virus infection and thyroid autoimmune disorders: A model of interactions between the host and the 
environment. World journal of hepatology8, 83-91.

Peng, Y.-C., Hsieh, S.-C., Yang, D.-Y., Tung, C.-F., Hu, W.-H., Huang, W.-N. and Chen, G.-H. (2001). Expression and clinical significance of antinuclear antibody in hepatitis $\mathrm{C}$ virus infection. Journal of clinical gastroenterology33, 402-406.

Rafik, M., Bakr, S., Soliman, D., Mohammed, N., Ragab, D., ElHady, W. A. and Samir, N. (2016). Characterization of differential antibody production against hepatitis $\mathrm{C}$ virus in different $\mathrm{HCV}$ infection status. Virol J13, 116.

Rania I.Mabrouk Yehia s.Younes, Y. A. S., Hala M.EL-feky,Maha Z.Omar,Rasha SH.EL-desouky,Rania Z., Eman G.Behiry (2015). Significance of Antinuclear Antibody Positivity in Chronic HCV Patients and Impact on Early Response to Combined Antiviral Therapy. The Medical Journal of Cairo University83, 275-282.

Rodrigues-Pinto, E., Cardoso, H., Pimenta, S. and Macedo, G. (2015). The Clinical Significance of Autoantibodies in Hepatitis C Patients Submitted to Interferon Treatment. GE Portuguese Journal of Gastroenterology22, 24-27.

Sezaki, H., Arase, Y., Tsubota, A., Suzuki, Y., Kobayashi, M., Saitoh, S., Suzuki, F., Akuta, N., Someya, T. and other authors (2003). Type C-chronic hepatitis patients who had autoimmune phenomenon and developed jaundice during interferon therapy. Journal of gastroenterology38, 493-500.

Squadrito, G., Previti, M., Lenzi, M., Le Rose, E. P., Caccamo, G., Restuccia, T., Di Cesare, E., Pollicino, T. and Raimondo, G. (2003). High prevalence of non-organ-specific autoantibodies in hepatitis $\mathrm{C}$ virus-infected cirrhotic patients from southern Italy. Digestive diseases and sciences 48, 349-353.

Tarantino, G., Sabatini, P., Soriente, I., Amato, P., Sangiolo, M. G. and Riccio, A. (2009). Circulating levels of interferon-gamma in course of hepatitis C virus-related arthritis. J Interferon Cytokine Res29, 389-392.

Tilg, H., Kaser, A. and Moschen, A. R. (2006). How to modulate inflammatory cytokines in liver diseases. Liver Int26, 1029-1039.

Yee, L. J., Kelleher, P., Goldin, R. D., Marshall, S., Thomas, H. C., Alberti, A., Chiaramonte, M., Braconier, J. H., Hall, A. J. and other authors (2004). Antinuclear antibodies (ANA) in chronic hepatitis $\mathrm{C}$ virus infection: correlates of positivity and clinical relevance. Journal of viral hepatitis 11 , 459-464.

Zignego, A. L., Ferri, C., Pileri, S. A., Caini, P. and Bianchi, F. B. (2007). Extrahepatic manifestations of Hepatitis C Virus infection: a general overview and guidelines for a clinical approach. Dig Liver Dis39, 2-17.

\section{How to cite this article:}

Helal F. Hetta, Azza Elkady, Khairy H. Morsy,Ismael S Mohamed, Khaled M. Hassanein, Tohamy A. Tohamy, Hala M. ElBadre and Ghada A. Mohamed. 2017. Circulating IL17a and IFN-Gamma Serum Levels in Cirrhotic Hepatitis C Virus Infected Patients with Autoimmune Thyroiditis. Int.J.Curr.Microbiol.App.Sci. 6(3): 1972-1983. doi: https://doi.org/10.20546/ijcmas.2017.603.225 